\begin{tabular}{cc}
\hline & COMPUTATIONAL RESEARCH PROGRESS IN APPLIED SCIENCE \& ENGINEERING (CRPASE) \\
\end{tabular}

\title{
Determination of Bioaccumulation Ratios and Antioxidant Activity of Lead and (+)- Catechin in Some Rat Tissues After Co-Administration
}

\author{
Semra Malkoc ${ }^{1 *}$, Hulyam Kurt ${ }^{2}$, Cansu Ozbayer ${ }^{3}$, Emine Yagci ${ }^{2}$ \\ ${ }^{1}$ Department of Environmental Engineering, Faculty of Engineering, Eskişehir Technical University, Eskişehir, Türkiye \\ ${ }^{2}$ Department of Medical Biology, Faculty of Medical, Eskişehir Osmangazi University, Eskişehir, Türkiye \\ ${ }^{3}$ Faculty of Health Sciences, Kütahya Health Sciences University, Kütahya, Türkiye
}

\begin{tabular}{|c|c|}
\hline Keywords & Abstract \\
\hline $\begin{array}{l}\text { Catechin, } \\
\text { Lead toxicity, } \\
\text { Rat, } \\
\text { Antioxidant Activity. }\end{array}$ & $\begin{array}{l}\text { Investigate the effects of the }(+) \text { - Catechin }(\mathrm{CTH}) \text { against the toxic Lead }(\mathrm{Pb}) \text { accumulation- } \\
\text { related oxidative stress in rat liver and also of bioaccumulation ratios in some rat tissues } \\
\text { Sprague-Dawley female rats were used. I. Control group: received }(0.5 \mathrm{ml} / \mathrm{kg} 0.9 \% \text { saline) } \\
\text { II. Pb intoxicated group: received }(20 \mathrm{mg} / \mathrm{kg} \mathrm{Pb}) \text { III. CTH supplemented group: received } \\
(20 \mathrm{mg} / \mathrm{kg} \mathrm{Pb})+(50 \mathrm{mg} / \mathrm{kg} \mathrm{CTH}) \text {. All doses were given intragastrically (i.g) and daily for } \\
15 \text { days. All animals were dissected after two weeks of treatment. Pb, levels were determined } \\
\text { in the colon, liver, stomach, pancreas, bladder, heart, kidney, and brain tissue by inductively } \\
\text { coupled plasma-optical emission spectrophotometer (ICP-OES } 720 \mathrm{ES}) \text {, after acid digestion } \\
\text { in all samples. The superoxide dismutase (SOD), malondialdehyde (MDA), and catalase } \\
\text { (CAT) levels were determined spectrophotometrically. Results were evaluated statistically. }\end{array}$ \\
\hline & $\begin{array}{l}\text { In the study, the most lead accumulation was determined in the bladder and the least } \\
\text { accumulation, respectively, colon, stomach, liver, kidney, brain, pancreas, and heart. We } \\
\text { found that CTH treatment increase liver CAT levels. We concluded that CTH may be } \\
\text { partially useful in Pb removal in some of the rat tissues. }\end{array}$ \\
\hline
\end{tabular}

\section{Introduction}

Heavy metals are natural components of the Earth's crust. Lead $(\mathrm{Pb})$ is a harmful environmental pollutant [1] in almost all of the environment and biological systems. Exposure to $\mathrm{Pb}$ results in significant accumulation in most of the vital organs. $\mathrm{Pb}$ binds to erythrocytes and via blood, it may transfer to the soft tissues. Some antioxidants are described to affect useful against $\mathrm{Pb}$ toxicity.

Lead $(\mathrm{Pb})$ is a heavy metal and is also present in trace amounts in soil, plants, and water. $\mathrm{Pb}$ is mostly distributed in the environment via natural and human-related activities [2, 3]. Exposure to $\mathrm{Pb}$ can lead to damage to several organs, including the liver, kidney, and also the main target is the peripheral and central nervous systems $[4,5]$. Firstly, $\mathrm{Pb}$ binds to erythrocytes and then it may transfer to some tissues including the kidney, liver, brain, muscles, heart, and spleen. Briefly, lead affects almost every organ of the living body depending on $\mathrm{Pb}$ toxicity [6].

Several kinds of research have shown that $\mathrm{Pb}$ can cause neurological, hematological, gastrointestinal, reproductive, circulatory, and immunological pathologies [7]. It has also been reported to increase the level of lipid peroxidation [8] and inhibit the activity of antioxidant enzymes (such as glutathione peroxidase, Catalase, and superoxide dismutase) [9].

Generally, easily soluble lead compounds have greater toxicity. Accordingly, these compounds such as lead nitrate,

* Corresponding Author: Semra Malkoc

E-mail address: Satik@eskisehir.edu.tr

Received: 11 November 2021; Revised: 24 December 2021; Accepted: 25 December 2021

https://doi.org/10.52547/crpase.7.4.2416

Academic Editor: Muhammad Ammar Khan

Please cite this article as: S. Malkoc, H. Kurt, C. Ozbayer, E. Yagci, Determination of Bioaccumulation Ratios and Antioxidant Activity of Lead and (+)-Catechin in Some Rat Tissues After Co-Administration, Computational Research Progress in Applied Science \& Engineering, CRPASE: Transactions of Applied Sciences 7 (2021) 1-5, Article ID: 2416. 
lead chloride, lead acetate, lead oxide, lead sulfide, and lead phosphate that are respectively sortable from lowest toxicity to high toxicity [10]. Lead is highly dangerous to live organisms reach high concentrations whose widespread use has caused extensive environmental contamination and health problems in many parts of the World $[11,12]$.

Almost all metals are detoxified in the liver. If they enter our body without being aware of large amounts, the liver couldn't handle this high loading and they join the recirculation and impair the functions of other organs [13]. Some endogenous (such as glutathione is an amino acid) and exogenous (Alpha Lipoic Acid, such as parsley) substances can contribute to the elimination of heavy metals from the body [14].

CTH is a high level of polyphenols that have antioxidant activity against free radical attacks and consist of flavanol monomers, also referred to as Catechins. Very studies have also demonstrated that tea (Camellia sinensis) is one of the most popular beverages worldwide $[15,16]$. Green tea is proposed to be the main preventive mechanism against various diseases including cancer, which has pathogenic oxidation events as a common causal background [17].

The relationship between $\mathrm{Pb}$ and distribution in mammalian organs like kidneys, liver, bile, and testis is also not clear. Therefore, investigating the effects of the coadministration of $\mathrm{Pb}$ and $\mathrm{CTH}$ that are antioxidant activity is necessary.

\section{Materials and Methods}

\subsection{Chemicals}

CTH ((+)-Catechin hydrate), and Lead (Pb) (Lead nitrate $\left.\mathrm{Pb}\left(\mathrm{NO}_{3}\right)_{2}\right)$ were purchased from Sigma-Aldrich (St. Louis, MO, USA).

\subsection{Animals}

Twenty-one female Sprague-Dawley rats between weighting 250 to $300 \mathrm{~g}$ were obtained from the Medical and Surgical Experimental Research Center (EskisehirTURKEY). Upon arrival, were given 1 week acclimation period in the Department of Biology, Eskisehir Osmangazi University, Science and Art Faculty's animal laboratory, during which they were housed in polycarbonate cages in a room with controlled temperature $\left(22 \pm 2{ }^{\circ} \mathrm{C}\right)$, humidity (50 $\pm 5 \%$ ), and a 12 hour light and dark cycle. During the experiment period, they were fed with laboratory pellet chows, and water was given ad libitum. This study was approved by the local Animal Ethics Committee of Eskisehir Osmangazi University, Turkey.

\subsection{Experimental Design}

The rats were randomly divided into the following groups (each containing seven animals and randomly assigned up to the mean weight distribution); Group I received normal $(0.9 \%)$ saline $(0.2 \mathrm{ml} / \mathrm{kg} /$ day $)$ (i.g), Group II received $\mathrm{Pb}(20$ $\mathrm{mg} / \mathrm{kg}$ /day) (i.g), daily in two divided doses, Group III received CTH (50 $\mathrm{mg} / \mathrm{kg} /$ day), (i.g) for fifteen days as pretreatments. In this period the previously treated group III $\mathrm{CTH}$ received at the same doses plus $\mathrm{Pb}$ at daily in two divided same doses via (i.g). Within 24 hours of the last dose, colon, liver, stomach, pancreas, bladder, heart, kidney, and brain tissue samples for determination of accumulation were collected from the rats using appropriate techniques under ether anesthesia. These samples were then stored at $-20{ }^{\circ} \mathrm{C}$ until analysis. The $\mathrm{Pb}$ level in the tissues was measured after acid digestion using the Microwave Digestive System (CEM, USA, model MARS 6). Example $(0.5 \mathrm{~g})$ was mixed with $10 \mathrm{ml}$ of $65 \% \mathrm{HNO}_{3}$ (Merck) in a Teflon vessel. The system $1600 \mathrm{~W} 800 \mathrm{psi}$ was heated to $200^{\circ} \mathrm{C}$ for 30 minutes. After cooling to ambient temperature, the solution was filtered through a nitrocellulose membrane $(0.45 \mathrm{um})$, then transferred to an acid-washed volumetric flask $(50 \mathrm{ml})$ and adjusted to a specific volume with double deionized water (Sartorius Arium 611VF). Blank digestion was performed in the same way. $\mathrm{Pb}$ accumulation was determined by Varian 720 ES model ICP-OES [18].

After the sacrificed, the liver tissues were quickly removed immediately with ice-cold normal saline, and homogenized in potassium chloride (1\%) using an ultrasonic homogenizer for enzyme assays. The homogenate was centrifuged at $4{ }^{\circ} \mathrm{C}$ for $15 \mathrm{~min}$ in a refrigerated centrifuge at $4000 \mathrm{rpm}$. The supernatant was used to assay superoxide dismutase (SOD), malondialdehyde (MDA), and catalase (CAT) activity. SOD activity was assayed according to the method of Sun et al [19]. In the method, the xanthine/xanthine oxidase system was used as the source of superoxide, which is the substrate of SOD, and nitroblue tetrazolium as an indicator of superoxide. The calculated SOD activity was given as \% inhibition. The measurement of MDA levels by thiobarbituric acid reactivity is the most commonly used method for assessing lipid peroxidation [20, 21]. In this method, $3 \mathrm{ml}$ of $1 \%$ phosphoric acid, $0.5 \mathrm{ml}$ of distilled water, and $1.0 \mathrm{ml}$ of $0.6 \%$ 2-thiobarbituric acid were added onto the obtained $0.1 \mathrm{ml}$ homogenate. The mixture was boiled in a water bath for 45 minutes, then cooled in ice. $4.0 \mathrm{ml}$ of $\mathrm{n}$-butanol was added to extract the cold thiobarbituric acid reactants. The optical density of the formed n-butanol layer was determined at $532 \mathrm{~nm}$ after centrifugation at $1.009 \mathrm{~g}$ for 5 minutes. The MDA levels are given as $\mathrm{nm} / \mathrm{ml}$. CAT activity was measured as previously described by Goth [22]. In the method, all samples containing $0.2 \mathrm{ml}$ of homogenate were incubated in $1.0 \mathrm{ml}$ of substrate solution at $37{ }^{\circ} \mathrm{C}$ for $60 \mathrm{~s}$. The reaction was stopped with ammonium molybdate solution $32.4 \mathrm{mmol} / \mathrm{l}$. Hydrogen peroxide was measured at $405 \mathrm{~nm}$ against a blank containing all the components except the enzyme on a spectrophotometer (Shimadzu UV-1601 spectrophotometer, Shimadzu Corp., Japan). The CAT activity was given as $\mathrm{kU} / \mathrm{g}$ protein.

\section{Result}

$\mathrm{Pb}$ accumulation was highest in the colon compared to the other groups. In the group supported by $\mathrm{CTH}$, lead accumulation decreased by $61.89 \%$ Figure 1 (a). In the liver, the group supported by $\mathrm{CTH}$, lead accumulation was effective in the removal of $23 \%$ Figure 1(b). In the stomach, CTH was effective in reducing lead accumulation by $38.87 \%$ Figure 1(c). In the group supported by CTH in the pancreas, the lead reduction was found to be $13.31 \%$ Figure $1(\mathrm{~d}) . \mathrm{CTH}$ was not effective in reducing the accumulation of $\mathrm{Pb}$ in the bladder that is the accumulation was very high. It was thought that this situation is caused by the attempted removal 
of the lead in the circulatory system from urine, feces, and sweating Figure 1(e). In the heart, CTH affected $9.28 \%$ in reducing lead accumulation Figure 1(f). In the kidney, $\mathrm{CTH}$ was effective in the removal of lead accumulation by $18.72 \%$ Figure $1(\mathrm{~g})$. In the CTH-supported group in the brain, $\mathrm{CTH}$ was effective in reducing lead accumulation by $13.75 \%$ Figure 1(h).
Statistical analyses were analyzed using IBM SPSS Statistics 21 software One-way ANOVA. The results of the statistical evaluation for SOD, MDA, and CAT levels were represented in Table 1. Briefly, no statistical differences were found in levels of liver SOD and MDA ( $\mathrm{P}>0,05)$. But when compared to control the liver CAT levels of the lead group were significantly decreased $(\mathrm{P}=0.033)$.

Table 1. SOD, MDA, and CAT levels of liver homogenate

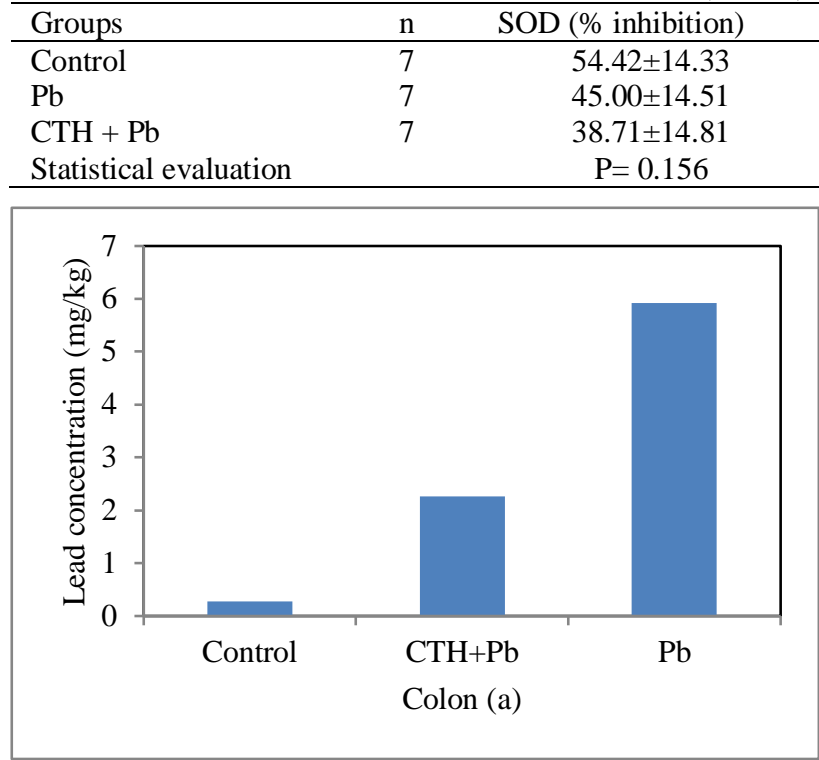

$\begin{array}{cc}\text { MDA (U/gr wet tissue) } & \text { CAT (kU/g protein) } \\ 9.90 \pm 2.19 & 269.97 \pm 200.86 \\ 11.80 \pm 1.58 & 71.62 \pm 27.46 \\ 11.97 \pm 2.24 & 165.31 \pm 148.20 \\ \mathrm{P}=0.135 & \mathrm{P}=0.033\end{array}$
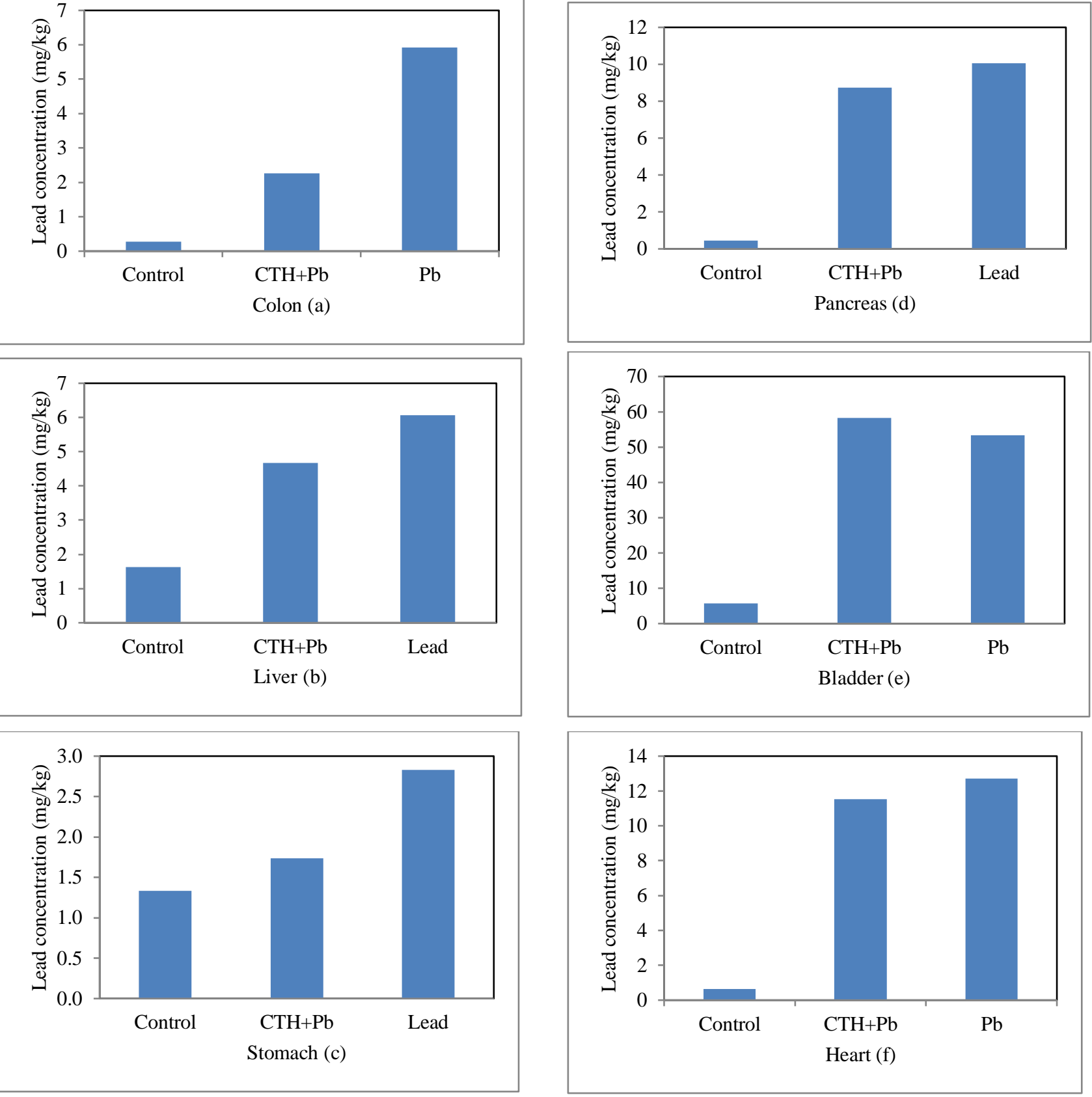

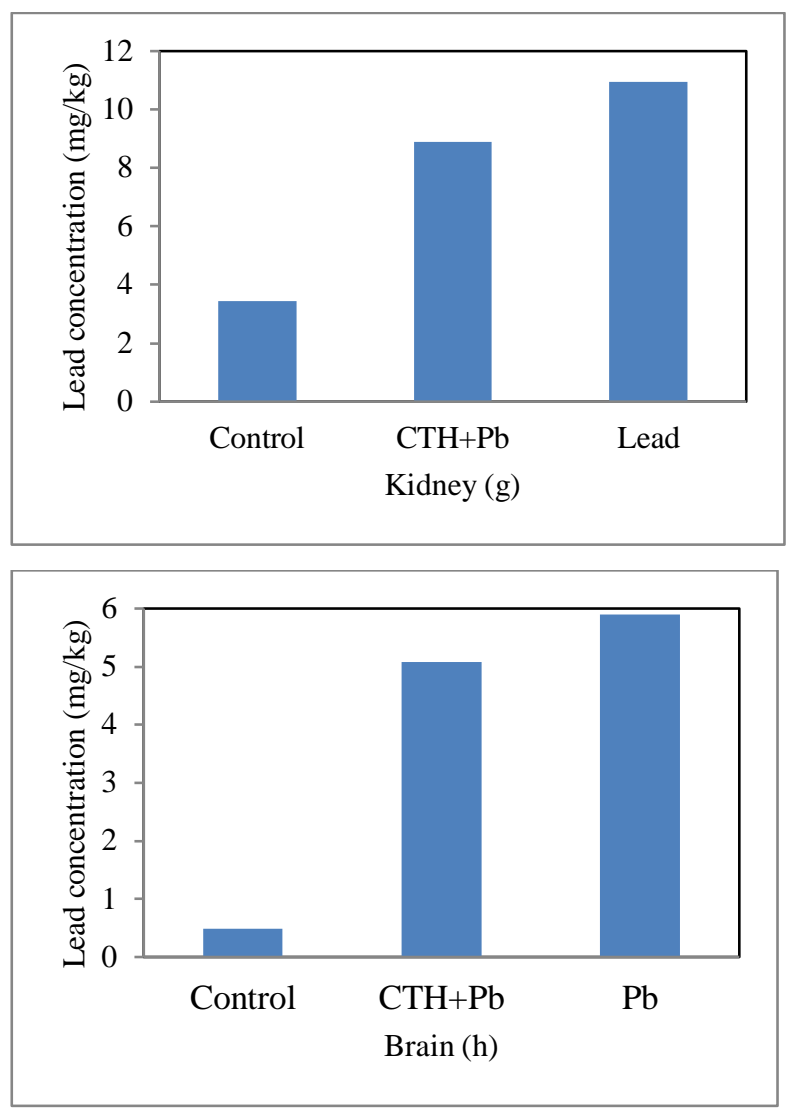

Figure 1. The concentration of $\mathrm{Pb}$ in some rat tissues

\section{Discussion}

Exposure to many environmental factors may be involved in the effect of metal toxicity, it is likely that it can cause many abnormalities or diseases, including disorders in the physiological balance of organisms and cancer and defense mechanisms [23]. Toxic elements accumulate over time in soft tissues and bone and are then removed. Toxic elements accumulate in soft tissues and bones over time.

The present study showed that exposure to lead causes lead accumulation in rat tissues, increasing the optimal level compared to a standard level. Furthermore, our data showed a reduction in the co-administration group. The elimination effect of CTH may be due to the radical scavenging activity of its components. These results indicated that the antioxidant properties of CTH may aid the mammalian body's ability to remove lead. In conclusion, we suggest that CTH is partially useful and plausible in the treatment of lead toxicity, but to support our findings in further studies, it may be necessary to use CTH in combination with a heavy metal chelating agent to increase its efficacy and increase lead excretion.

Free oxygen radicals (SOR) and antioxidants are produced in living tissues in a continuously controlled manner. To maintain tissue integrity and function, overproduced SOR needs to be neutralized by SOD, CAT, and other antioxidants with vitamins A, C, E. SOR causes the formation of the main toxic metabolite formed by the oxidation of cell membrane lipids such as malondialdehyde (MDA). It is thought that the SOD enzyme should be examined together with the catalase enzyme to prevent this destructive effect. Because hydrogen peroxide formed at the end of the reaction catalyzed by SOD is one of the toxic oxygen species and its accumulation with catalase is prevented [24, 25].

The increase in lipid peroxidation due to SOR in intracellular and extracellular membranes indicates that the increase in MDA, which is an indicator of this, damages organs, tissues, and cells. It causes physiological and biochemical changes in humans and animals related to leadinduced oxidative damage. It has been reported that the lipid peroxidation-inducing effects of lead are associated with the binding of amino acids, proteins, and antioxidant enzymes such as GSH-Px, SOD, and CAT to thiol groups, an increase in SOR, and a consequent deterioration in tissue integrity [26].

The liver and kidney play a primary role in the biotransformation and elimination of lead, so lead may exert more harmful effects on these organs. Similar to some studies, when we look at some antioxidant enzyme concentrations such as lipid peroxidation indicator MDA, SOD, and CAT in our study in determining lead-induced oxidative damage in liver tissue, which is one of the organs most affected by lead, it is clear that lead triggers lipid peroxidation and inhibits antioxidant enzymes. One reason lead decreases SOD activity may be the interaction between lead and Zn. While CTH treatment was expected to increase the SOD enzyme level, it was determined that it was not effective. The decrease in CAT activity is thought to be due to the excessive accumulation of $\mathrm{H}_{2} \mathrm{O}_{2}$ in mitochondria and peroxisome cytosols and indirectly to a decrease in SOD activity.

Chelation with molecules such as calcium disodium ethylenediaminetetraacetic acid $\left(\mathrm{CaNa}_{2}\right.$ EDTA) and meso 2,3-dimercaptosuccinic acid (DMSA) against heavy metal toxicity is the best-known treatment to date. However, these treatments may cause other side effects for the body due to their effects such as inhibition of essential metals required for the body and inability to pass through cell membranes. For this reason, the use of non-toxic molecules such as green or black tea, which can cross the blood-brain barrier (BBB), as well as metal chelating and antioxidant properties, is becoming more common in eliminating heavy metal toxicity [27].

Areba et al. [27], conducted a study, the modulatory effects of black and green tea extracts from Kenya on cadmium toxicity were evaluated. In this study, black and green tea treatment was compared with $\mathrm{Na}_{2}$ EDTA treatment on experimentally induced cadmium toxicity in brain, liver, kidneys, bone, and testes of male Wistar albino rats. Subcutaneous administration of cadmium chloride has been found to induce renal, hepatic, neuronal, testicular, and bone damage. In the study, Co-administration of aqueous black or green tea extracts along with $\mathrm{Cd}$ resulted in a reversal of $\mathrm{Cd}$ induced biochemical changes in the liver and brain accompanied by a significant decrease in lipid peroxidation and an increase in the level of hepatic, neuronal, testicular, and renal antioxidant. The study findings demonstrated that like our study the cytoprotective potential of tea in $\mathrm{Cd}$ toxicity to its antioxidant and metal chelating properties. 


\section{Conclusion}

As a result, when we evaluated the oxidative stress parameters, we could not find a statistical correlation between CTH treatment, SOD, and MDA levels. However, we found that $\mathrm{CTH}$ therapy increased liver CAT levels. Antioxidant defense systems enzymatic and non-enzymatic It has complex antioxidant defense mechanisms. As the first line of defense, we can say that the increase in CAT, which is one of the enzymes that suppress the formation of SOR, protects the liver by supporting it. This study was planned to increase the antioxidant status and/or decrease oxidative stress and reduce heavy metal accumulation with the application of antioxidants. After CTH combined application to remove $\mathrm{Pb}$-bound accumulation, it was determined that the highest accumulation was in the bladder and the least accumulation was in the colon, stomach, liver, kidney, brain, pancreas, and heart, respectively. At the end of the study, it was found that $\mathrm{CTH}$ was partially beneficial in eliminating $\mathrm{Pb}$ accumulation in rat tissues. Accordingly, we think that further studies are needed to use CTH in combination with a heavy metal chelating agent to increase its effectiveness.

\section{Conflict of interest statement}

The authors declare no conflict of interest.

\section{References}

[1] S.Y. Mousavi, A. Mousavi, Modeling Pollutants Emissions in Iron and Steel Industry (Case Study: Iranian Glader Iron \& Steel Company), Computational Research Progress in Applied Science and Engineering (CRPASE) 02 (2016) 89-92.

[2] M. Ahamed, S. Singh, J.R. Behari, A. Kumar, M.K.J. Siddiqui, Interaction of lead with some essential trace metals in the blood of anemic children from Lucknow, India. Clinica chimica acta, 377 (2007) 92-97.

[3] $\mathrm{H}$. Cheng, Y. Hu, Lead $(\mathrm{Pb})$ isotopic fingerprinting and its applications in lead pollution studies in China: a review, Environmental Pollution 158 (2010) 1134-1146.

[4] H. Needleman, Lead poisoning, Annual Review of Medicine, 55 (2004) 209-222.

[5] S. Dai, Z. Yin, G. Yuan, H. Lu, R. Jia, J. Xu, X. Song, L. Li, Y. Shu, X. Liang, C. He, C. Lv, W. Zhang, Quantification of metallothionein on the liver and kidney of rats by subchronic lead and cadmium in combination, Environmental toxicology and pharmacology 36 (2013) 1207-1216.

[6] P. A. Meyer, M. J. Brown, H. Falk, Global approach to reducing lead exposure and poisoning, Mutation Research/Reviews in Mutation Research 659 (2008) 166-175.

[7] L. Patrick, Lead toxicity part II: the role of free radical damage and the use of antioxidants in the pathology and treatment of lead toxicity, Alternative Medicine Review 11 (2006) 14.

[8] C. Upasani, R., Balaraman, Protective effect of Spirulina on lead-induced deleterious changes in the lipid peroxidation and endogenous antioxidants in rats, Phytotherapy Research, An International Journal Devoted to Pharmacological and Toxicological Evaluation of Natural Product Derivatives 17 (2003) 330-334.

[9] N. Ercal, H. Gurer-Orhan, N. Aykin-Burns, Toxic metals, and oxidative stress part I: mechanisms involved in metal-induced oxidative damage, Current Topics in Medicinal Chemistry 1 (2001) 529-539.

[10] S. Toplan, D. Ozcelik, T. Gulyasar, M.C. Akyolcu, Changes in hemorheological parameters due to lead exposure in female rats, Journal of Trace Elements in Medicine and Biology 18 (2004) 179-182.
[11] P. Sharma, R.S. Dubey, Lead toxicity in plants, Brazilian Journal of Plant Physiology 17 (2005) 35-52.

[12] S. Malkoc, H. Kurt, C. Ozbayer, E. Yagci, Mycoremediation of Trichoderma harzianum and Penicillium chrysogenum to $\mathrm{Pb}$ Exposure: Effect on Metal Bioaccumulation, Oxidative Stress and Antioxidant System, CRPASE Computational Research Progress in Applied Science and Engineering 7(2) (2021) 1-4.

[13] T. Kunito, S. Nakamura, T. Ikemoto, Y. Anan, R. Kubota, S. Tanabe, F.C.W. Rosas, G. Fillmann, J.W. Readman, Concentration and subcellular distribution of trace elements in the liver of small cetaceans incidentally caught along the Brazilian coast, Marine Pollution Bulletin 49 (2004) 574-587.

[14] M. E. Sears, Chelation: harnessing and enhancing heavy metal detoxification - a review, The Scientific World Journal (2013) 219840.

[15] R. Ogura, N. Ikeda, K. Yuki, O. Morita, K. Saigo, C. Blackstock, N. Nishiyama, T. Kasamatsu, Genotoxicity studies on green tea catechin, Food and Chemical Toxicology 46 (2008) 2190-2200.

[16] K.V.P. Chandra Mohan, Y. Hara, S.K. Abraham, S. Nagini, Comparative evaluation of the chemopreventive efficacy of green and black tea polyphenols in the hamster buccal pouch carcinogenesis model, Clinical Biochemistry 38 (2005) 879886.

[17] L. Elbling, R.M. Weiss, O. Teufelhofer, M. Uhl, S. Knasmueller, R. Schulte-Hermann, W. Berger, M. Micksche, Green tea extract and (-)-epigallocatechin-3- gallate, the major tea catechin, exert oxidant but lack antioxidant activities, The FASEB Journal 19 (2005) 807-809.

[18] E. Yamac, M. Ozden, S. Balaban, S. Malkoc, Heavy metal accumulation as a threat to the endangered Egyptian vulture (Neophron percnopterus L.) in Turkey, Turkish Journal of Zoology 43 (2019) 628-635.

[19] Y.I. Sun, L.W. Oberley, Y. Li, A simple method for clinical assay of superoxide dismutase, Clinical Chemistry 34(1988) 497-500.

[20] M. Uchiyama, M. Mihara, Determination of malonaldehyde precursor in tissues by thiobarbituric acid test, Analytical Biochemistry 86 (1978) 271-278.

[21] C. Ozbayer, H. Kurt, Z. Ozdemir, T. Tuncel, S. Moheb Saadat, D. Burukoglu, H. Senturk, I. Degirmenci, H.V. Gunes, Gastroprotective, cytoprotective and antioxidant effects of Oleum cinnamomi on ethanol-induced damage, Cytotechnology 66 (2014) 431-441.

[22] L. Goth, A simple method for determination of serum catalase activity and revision of reference range, Clinica Chimica Acta 196 (1991) 143-151.

[23] M. Wieloch, P. Kaminski, A. Ossowska, KoimPuchowska B.: Do toxic heavy metals affect antioxidant defense mechanisms in humans? Ecotoxicology and Environmental Safety 78 (2012) 195-205.

[24] R. Aslankoç, D. Demirci, Ü. İnan, M. Yıldız, A. Öztürk, M. Çetin, E.Ş. Savran, B. Yılmaz, Oksidatif stres durumunda antioksidan enzimlerin rolü-Süperoksit dismutaz (SOD), katalaz (CAT) ve glutatyon peroksidaz (GPX). SDÜ Tip Fakültesi Dergisi 26 (2019) 362-369.

[25] H. Süleyman, V. Gül, E. Erhan, Oksidatif stres ve doku hasarı, Erzincan Tip Dergisi 1 (2018) 1-4.

[26] R. Sivaprasad, M. Nagaraj, P. Varalakshmi, Combined efficacies of lipoic acid and 2, 3-dimercaptosuccinic acid against lead-induced lipid peroxidation in rat liver. The Journal of nutritional biochemistry 15 (2004) 18-23.

[27] G.O. Areba, Determination of antioxidant and metal chelating properties of tea (camelia sinensis) in ameliorating cadmiuminduced toxicity in male Wistar rats. Egerton University, (2020). 